\title{
Pengaruh Amplitudo dan Frekuensi terhadap Fenomena Pemuncakan
}

\author{
Wuryansari Muharini Kusumawinahyu \\ Jurusan Matematika FMIPA, Universitas Brawijaya \\ Jl. Veteran Malang 65145, Indonesia. \\ e-mail: wmuharini@yahoo.com
}

\begin{abstract}
Abstrak
Telah diketahui bahwa suatu signal bikromatik yang diberikan sebagai masukan di pembangkit gelombang di laboratorium hidrodinamika mengalami fenomena pemuncakan ketika ia merambat di sepanjang kolam pengujian. Dengan memanfaatkan besaran yang disebut Maximal Temporal Amplitude (MTA), dikaji pengaruh amplitudo dan frekuensi selubung signal gugus gelombang di pembangkit gelombang terhadap faktor amplifikasi dan posisi terjadinya elevasi maksimum. Data untuk penyelidikan ini dibangkitkan dengan menggunakan suatu simulasi numerik pembangkitan dan perambatan gelombang di sepanjang kolam pengujian dua dimensi. Hasil yang diperoleh dibandingkan dengan hasil yang diperoleh secara analitik menggunakan aproksimasi orde ke tiga persamaan $\mathrm{KdV}$.
\end{abstract}

Kata Kunci: gelombang bikromatik, fenomena pemuncakan, amplitudo, frekuensi, Maximal Temporal Amplitude, faktor amplifikasi.

\section{Pendahuluan}

Gelombang bikromatik merupakan superposisi dua gelombang monokromatik dengan amplitudo dan frekuensi tertentu sehingga dapat dinyatakan sebagai gugus 
gelombang dengan selubung yang khas. Berbagai penelitian mengenai pembangkitan gelombang memberikan kesimpulan bahwa suatu signal bikromatik yang diberikan sebagai masukan di pembangkit gelombang di laboratorium hidrodinamika akan mengalami perubahan bentuk dan elevasinya meninggi ketika ia merambat di sepanjang kolam pengujian. Lo dan Mei[11] adalah peneliti pertama yang melaporkan evolusi gugus gelombang bikromatik yang tak stabil dalam jangka waktu evolusi yang lama. Hasil pengukuran yang dilakukan oleh G.J. Keller dalam [11] memperlihatkan bahwa gelombang yang semula simetri menjadi tak simetri dan meningkat kecuramannya di bagian depan dan melandai di bagian belakang. Dengan menggunakan skema numerik, Lo dan Mei [11] juga mengamati terjadinya pemisahan (splitting) gugus gelombang bikromatik menjadi dua gugus gelombang dengan kecepatan yang berlainan. Eksperimen serupa dilakukan pula oleh Stansberg pada tahun 1997. Hasil eksperimen Stansberg [13] memperlihatkan bahwa gelombang permukaan yang pada pembangkit gelombang berupa signal bikromatik, dengan amplitudo $q=0,08 \mathrm{~m}$ dan frekuensi $\omega_{1}=3,3 \mathrm{rad} / \mathrm{dt}$ dan $\omega_{2}=2,99 \mathrm{rad} / \mathrm{dt}$, dalam perambatannya mengalami deformasi selubung, berupa gejala peaking (pemuncakan) dan splitting.

Dalam penelitian ini dikaji pengaruh amplitudo dan frekuensi selubung signal gugus gelombang di pembangkit gelombang terhadap faktor amplifikasi dan posisi terjadinya elevasi maksimum, yang selanjutnya disebut posisi maksimum. Untuk itu diperkenalkan besaran yang dapat digunakan untuk menentukan faktor amplifikasi dan posisi maksimum secara global. Besaran yang dimaksud adalah Maximal Temporal Amplitude (MTA) yang merupakan nilai maksimum elevasi signal gelombang di setiap posisi. Data yang digunakan dalam penyelidikan ini dibangkitkan dengan menggunakan simulasi numerik pembangkitan dan perambatan gelombang di sepanjang kolam pengujian dua dimensi, yang disebut HUBRIS. Hasil yang diperoleh secara numerik tersebut dibandingkan dengan hasil yang diperoleh secara analitik dengan menggunakan aproksimasi orde ke tiga persamaan KdV.

Makalah ini disusun mengikuti urutan berikut. Pertama diulas secara rinci mengenai gugus gelombang bikromatik untuk memperlihatkan pentingnya gugus gelombang tersebut. Kemudian dijelaskan mengenai persamaan lengkap dan model numerik HUBRIS. Pada bagian berikutnya diberikan definisi mengenai Maximal Temporal Amplitude (MTA), posisi maksimum dan faktor amplifikasi. Secara analitik, perhitungan MTA dapat dilakukan dengan menggunakan hampiran orde ke tiga solusi persamaan KdV. Dengan menggunakan MTA diselidiki pengaruh amplitudo dan frekuensi selubung signal bikromatik di pembangkit gelombang terhadap posisi maksimum dan faktor amplifikasi. Hasil perhitungan dan pembahasannya diberikan pada bagian 5. Makalah ini diakhiri dengan kesimpulan pada bagian 6 . 


\section{Gugus Gelombang Bikromatik}

Gelombang bikromatik yang dikaji dalam makalah ini adalah gugus gelombang yang dihasilkan oleh superposisi dua gelombang monokromatik dengan frekuensi yang berbeda, yaitu

$$
\eta(x, t)=q \cos \left(k_{1} x-\omega_{1} t\right)+q \cos \left(k_{2} x-\omega_{2} t\right)=2 q \cos (\kappa x-\nu t) \cos (\bar{k} x-\bar{\omega} t),
$$

dengan

$$
\bar{k}=\frac{k_{1}+k_{2}}{2}, \quad \kappa=\frac{k_{1}-k_{2}}{2}, \quad \bar{\omega}=\frac{\omega_{1}+\omega_{2}}{2}, \text { dan } \nu=\frac{\omega_{1}-\omega_{2}}{2} .
$$

Dari persamaan tersebut terlihat bahwa gugus gelombang bikromatik terdiri atas gelombang pembawa berfrekuensi $\bar{\omega}$ yang dimodulasi oleh selubung gelombang berfrekuensi $\nu$. Cepat rambat selubung gelombang tersebut adalah $\nu / \kappa$ dan disebut sebagai kecepatan gugus gelombang bikromatik.

Hasil menarik yang diperoleh Lo, Mei, dan Stansberg mendorong peneliti lain melakukan penyelidikan lebih mendalam terhadap fenomena deformasi gugus gelombang bikromatik. Penjelasan analitis terhadap sebagian fenomena yang ditemukan Stansberg diberikan oleh van Groesen dkk. [8]. Mereka menggunakan persamaan fase-amplitudo dari persamaan NLS untuk menjelaskan bahwa terjadinya fenomena tersebut disebabkan oleh adanya koreksi terhadap kecepatan fase dan kecepatan gugus yang tidak lagi hanya dipengaruhi oleh bilangan gelombang melainkan dipengaruhi pula oleh amplitudo. Westhuis dkk. [15] melakukan penyelidikan dengan membangkitkan gelombang bikromatik di laboratorium hidrodinamika menggunakan beberapa amplitudo dan frekuensi selubung yang berbeda-beda. Hasil eksperimen Westhuis dkk. [15] memperlihatkan bahwa deformasi yang besar dengan peningkatan elevasi gelombang yang tinggi dipengaruhi oleh perbandingan antara amplitudo dan selisih frekuensi kedua gelombang monokromatik yang membentuk gelombang bikromatik. Salah satu eksperimen mereka menggunakan parameter yang sama dengan eksperimen Stansberg. Selain itu, dalam [15] dan [14] disajikan pula hasil rekonstruksi eksperimen Stansberg yang dilakukan secara numerik menggunakan HUBRIS.

Usaha untuk memahami fenomena deformasi gelombang bikromatik dilakukan pula oleh Cahyono [4] dengan membangun analytical wave code (AWC) yang memberikan koreksi terhadap bilangan gelombang. Penelitian yang dilakukan oleh Cahyono kemudian diperbaiki oleh Andonowati dkk. dalam [12, 3], yang dikemukakan sekilas pada bagian 4 . 


\section{Persamaan Lengkap dan Model Numerik}

Perhatikan gelombang yang merambat pada suatu lapisan fluida dengan kedalaman $h$ di atas dasar rata pada suatu kolam. Misalkan fluida tersebut diasumsikan homogen, tak kental, tak termampatkan dan tak terotasi. Bila diasumsikan gelombang merambat tanpa batas hanya dalam arah horisontal searah dengan sumbu $x$ dan tekanan permukaan diabaikan, maka potensial kecepatan fluida $\phi(x, z, t)$ adalah solusi persamaan Laplace

$$
\frac{\partial^{2} \phi}{\partial x^{2}}+\frac{\partial^{2} \phi}{\partial z^{2}}=0, \quad-h \leq z \leq \eta(x, t) .
$$

Persamaan tersebut dilengkapi dengan syarat-syarat batas berikut:

$$
\begin{aligned}
& \frac{\partial \phi}{\partial z}=0, z=-h \\
& \frac{\partial \eta}{\partial t}+\frac{\partial \phi}{\partial x} \frac{\partial \eta}{\partial x}=\frac{\partial \phi}{\partial z}, z=\eta(x, t), \\
& g \eta+\frac{\partial \phi}{\partial t}+\frac{1}{2}\left[\left(\frac{\partial \phi}{\partial x}\right)^{2}+\left(\frac{\partial \phi}{\partial z}\right)^{2}\right]=0, z=\eta(x, t),
\end{aligned}
$$

dengan $\eta(x, t)$ menyatakan elevasi permukaan fluida yang diasumsikan bernilai tunggal. Persamaan (1) hingga (4) dikenal sebagai persamaan lengkap ( full equation), sebagaimana diungkapkan dalam buku-buku teks baku tentang gelombang seperti $[1,5,6]$.

Solusi eksak persamaan lengkap tersebut tidak mudah ditentukan, karena syarat batas kinematik dan dinamik melibatkan potensial kecepatan $\phi(x, t, z)$ dan elevasi permukaan $\eta(x, t)$ secara simultan dalam bentuk tak linier. Selain itu, persamaan lengkap (1)-(4) belum melibatkan syarat batas pada arah horisontal karena arah horisontal dianggap tak terbatas. Model matematika gerakan air di kolam hidrodinamika memerlukan syarat batas pada sisi pembangkit gelombang dan pada sisi lain yang menyerupai pantai dan berfungsi sebagai penyerap agar tidak terjadi gelombang pantul. Selama ini belum diperoleh solusi analitik eksak yang mendeskripsikan dinamika gelombang permukaan air di sepanjang kolam hidrodinamika karena rumitnya formulasi syarat batas. Berdasarkan persamaan Laplace yang dilengkapi dengan syarat batas di pembangkit gelombang dan sisi penyerap, Westhuis [14] telah membangun suatu model numerik yang disebut HUBRIS. Model numerik tersebut mensimulasikan pembangkitan dan perambatan dalam satu arah gelombang permukaan bebas tak linier dua dimensi yang deterministik di kolam hidrodinamika. HUBRIS telah diuji dengan percobaan di laboratorium hidrodinamika Maritime Research Institute Netherlands (MARIN), Wageningen, Belanda, dan menunjukkan kesesuaian yang cukup akurat. Bila pada model numerik tersebut diberikan masukan berupa signal $\eta(t)$ pada pembangkit gelombang, 
maka akan diperoleh keluaran berupa data elevasi gelombang permukaan air $\eta(x, t)$ dan potensial kecepatan air $\phi(x, z, t)$, dengan $(x, z, t)$ menyatakan koordinat ruang dan waktu fisis di laboratorium hidrodinamika. Model numerik HUBRIS yang digunakan dalam penelitian ini adalah HUBRIS versi 2.0 dengan masukan berupa signal polikromatik tanpa tambahan fase

$$
\eta(t)=\sum_{j=1}^{m} a_{j} e^{i\left(\omega_{j} t\right)}+c . c .
$$

dengan $1 \leq m \leq 10$ dan c.c. menyatakan complex conjugate (kompleks sekawan) suku sebelumnya.

\section{Maximal Temporal Amplitude (MTA)}

Untuk mengamati perilaku global elevasi gelombang dalam perambatannya di sepanjang kolam pengujian, digunakan suatu parameter yang disebut Maximal Temporal Amplitude (MTA). Parameter yang menyatakan nilai maksimum elevasi signal gelombang di setiap posisi tersebut telah digunakan dalam [2] untuk menyelidiki deformasi gelombang optik. Untuk masalah perambatan gelombang air di sepanjang kolam hidrodinamika, MTA yang didefinisikan sebagai

$$
\mathcal{M}(x)=\max _{t} \eta(x, t)
$$

dapat diartikan sebagai tinggi bagian dinding kolam pada sisi panjang yang terbasahi oleh air selama gelombang merambat, bila diukur dari permukaan air tenang $z=0$. Untuk mengetahui besarnya perubahan elevasi gelombang secara global, diamati perbandingan antara nilai MTA tertinggi dan nilai MTA di posisi pembangkit gelombang. Perbandingan itu disebut Faktor Amplifikasi Amplitudo (FAA) yang didefinisikan sebagai

$$
F A A=\frac{\max \mathcal{M}(x)}{\mathcal{M}(0)} .
$$

Posisi maksimum yang dinotasikan sebagai $x_{\max }$ dapat ditentukan dengan menggunakan MTA dengan menentukan posisi di mana pertama kali MTA mencapai maksimum. Nilai elevasi $\eta(x, t)$ dan tinggi selubung $A(x, t)$ yang digunakan untuk menghitung MTA dapat diperoleh secara analitik atau numerik.

Secara analitik, Andonowati dan Marwan dalam [3] merumuskan nilai $\eta(x, t)$ untuk gelombang bikromatik dan gelombang trikromatik melalui aproksimasi orde ke tiga solusi persamaan KdV, yang selanjutnya disingkat dengan AOT-KdV. Persamaan KdV merupakan hampiran persamaan lengkap yang memodelkan elevasi gelombang permukaan yang cukup rendah dan cukup panjang, serta merambat 
dalam satu arah. Persamaan KdV diperoleh melalui proses uni-directionalisation. Persamaan KdV telah diperbaiki oleh van Groesen [7] menjadi persamaan berikut.

$$
\frac{\partial \eta}{\partial t}+i \Omega\left(-i \frac{\partial}{\partial x}\right) \eta=-C_{0} \eta \frac{\partial \eta}{\partial x},
$$

dengan $\Omega(k)=\sqrt{k \tanh (k)}$ adalah relasi dispersi linier yang mengaitkan frekuensi $\omega$ dengan bilangan gelombang $k$ dalam koordinat yang dinormalkan, $C_{0}$ suatu konstanta yang menyatakan koefisien ketaklinieran, dan $\eta(x, t)$ adalah elevasi gelombang dalam koordinat yang dinormalkan. Kaitan antara koordinat yang dinormalkan dengan koordinat fisis adalah

$$
\eta_{l a b}=h \eta, \quad x_{l a b}=h x, \quad t_{l a b}=\sqrt{\frac{h}{g}} t, \quad k_{l a b}=\frac{k}{h}, \quad \omega_{l a b}=\sqrt{\frac{g}{h}} \omega .
$$

Solusi $\eta(x, t)$ yang diperoleh melalui AOT-KdV adalah solusi $\eta(x, t)$ yang berbentuk

$$
\eta(x, t)=\varepsilon \eta^{(1)}(x, t)+\varepsilon^{2} \eta^{(2)}(x, t)+\varepsilon^{3} \eta^{(3)}(x, t)+\ldots,
$$

dengan $\varepsilon$ adalah suatu parameter positif yang kecil yang menyatakan orde amplitudo elevasi. Pada orde pertama diambil solusi

$$
\eta^{(1)}(x, t)=\sum_{p=1}^{m} a_{p} e^{i\left(k_{p} x-\omega_{p} t+\psi_{p}\right)}+c . c .,
$$

dengan $\omega_{p}=\Omega\left(k_{p}\right)$. Untuk $m=2$ dan $m=3$, maka berturut-turut diperoleh gugus gelombang bikromatik dan gelombang trikromatik. Untuk menghindari resonansi, dilakukan koreksi terhadap bilangan gelombang, dengan menyatakan bilangan gelombang sebagai $k_{p}^{n l}=k_{p}+\varepsilon k_{p}^{(1)}+\varepsilon^{2} k_{p}^{(2)}+\mathcal{O}\left(\varepsilon^{3}\right)$, dengan $k_{p}=\Omega^{-1}\left(\omega_{p}\right)$. Substitusi persamaan (9) ke persamaan $\mathrm{KdV}(7)$ menghasilkan polinom dalam $\varepsilon$. Dengan mengumpulkan koefisien polinom tersebut di setiap orde $\varepsilon$ diperoleh persamaan diferensial linier di setiap orde. Solusi persamaan diferensial pada orde yang lebih tinggi diperoleh dengan menggunakan solusi persamaan diferensial pada orde yang lebih rendah. Dengan cara tersebut diperoleh solusi

$$
\eta(x, t)=\eta^{(1)}(x, t)+\eta^{(2)}(x, t)-\eta_{f w}^{(2)}(x, t)+\eta^{(3)}(x, t)-\eta_{f w}^{(3)}(x, t),
$$

dengan $\eta_{f w}^{(j)}(x, t), j=2,3$ menyatakan solusi free wave, yaitu solusi yang perlu ditambahkan untuk mengkompensasi munculnya solusi orde ke dua dan ke tiga di pembangkit gelombang.

Untuk kasus gelombang bikromatik, dalam [3] diambil gelombang bikromatik khusus dengan $a_{1}=a_{2}=q$ sebagai solusi orde pertama, yaitu

$$
\eta(x, t)^{(1)}=q \cos \left(k_{1}^{n l} x-\omega_{1} t+\psi_{1}\right)+q \cos \left(k_{2}^{n l} x-\omega_{2} t+\psi_{2}\right)
$$


Dengan menggunakan solusi tersebut dalam definisi MTA (5), Andonowati dan Marwan dalam [3] merumuskan $x_{\max }$ untuk gelombang bikromatik tersebut, sebagai

$$
x_{\max }=\frac{\pi}{|\bar{k}-\bar{\Omega}|}=\frac{\pi}{2\left|\nu^{2} K^{\prime \prime}(\bar{\omega})+q^{2}\left(\tilde{\gamma}+\frac{C_{0}^{2} \sigma_{2} K(\bar{\omega})}{\Omega^{\prime}(K(\bar{\omega}))}\right)\right|}=\mathcal{O}\left(\frac{1}{\nu^{2}}, \frac{1}{q^{2}}\right),
$$

dengan $\bar{k}=\left(k_{1}^{n l}+k_{2}^{n l}\right) / 2, \kappa=\left|k_{1}^{n l}-k_{2}^{n l}\right| / 2, \bar{\omega}=\left(\omega_{1}+\omega_{2}\right) / 2, \nu=\left|\omega_{1}-\omega_{2}\right| / 2$, $\bar{\Omega}=(K(\bar{\omega}+3 \nu)+K(\bar{\omega}-3 \nu)) / 2, \quad \tilde{\gamma}=C_{0}^{2} \bar{k}\left(\sigma_{0}+\sigma_{2}\right), \quad \sigma_{0}=\frac{1}{\Omega^{\prime}(K(\bar{\omega}))-\Omega^{\prime}(0)}$, $\sigma_{2}=\frac{K(\bar{\omega})}{2 \bar{\omega}-\Omega(2 K(\bar{\omega}))}$ dan $K^{\prime \prime}$ menyatakan turunan ke dua $K$. Dari hasil tersebut dapat disimpulkan bahwa nilai $x_{\max }$ tidak dipengaruhi oleh tambahan fase $\psi_{1}$ maupun $\psi_{2}$ melainkan hanya dipengaruhi oleh amplitudo, $q$, dan frekuensi selubung, $\nu$.

\section{Hasil dan Pembahasan}

\subsection{Pengaruh Amplitudo}

Nilai $\eta(x, t)$ diperoleh dari keluaran program paket HUBRIS yang mensimulasikan pembangkitan dan perambatan gelombang di kolam pengujian. Oleh sebab itu koordinat yang digunakan adalah koordinat fisis, dengan kedalaman kolam $h=$ $5 \mathrm{~m}$ dan percepatan gravitasi $g=9,81 \mathrm{~m} / \mathrm{dt}^{2}$. Semua nilai diberikan dalam koordinat fisis dengan sistem satuan $(m, k g, d t)$. Masukan yang diberikan di pembangkit gelombang adalah signal

$$
\eta(0, t)=q \cos \left(\omega_{1} t\right)+q \cos \left(\omega_{2} t\right)=2 q \cos (\nu t) \cos (\bar{\omega} t) .
$$

Kebergantungan $\eta(x, t)$ terhadap rasio antara $q$ dan $\nu$ telah dikaji dalam $[15,4,9]$, namun belum diketahui kebergantungan perilaku MTA, $\mathcal{M}(x)$, terhadap kedua parameter tersebut. Untuk menyelidiki pengaruh amplitudo dan frekuensi selubung gelombang bikromatik terhadap $F A A$ dan $x_{\max }$, digunakan beberapa nilai amplitudo $q$ dan frekuensi selubung $\nu$ signal bikromatik di pembangkit gelombang, dengan $\bar{\omega}=3,145 / \mathrm{dt}$.

Pertama-tama, untuk memusatkan perhatian pada pengaruh amplitudo, frekuensi selubung diambil konstan, yaitu $\nu=0,155$, sedangkan amplitudo diambil bervariasi, yaitu $0,01 \leq q \leq 0,09$. Untuk mengilustrasikan perubahan $x_{\max }$ dan FAA terhadap $q$, dalam Gambar 1 diperlihatkan kurva MTA evolusi gelombang air di permukaan, yang di posisi $x=0$ berupa signal bikromatik dengan $0,01 \leq q \leq 0,03$. Dalam [8] gelombang bikromatik tersebut digolongkan sebagai gelombang rendah. Gelombang-gelombang tersebut belum memperlihatkan gejala 


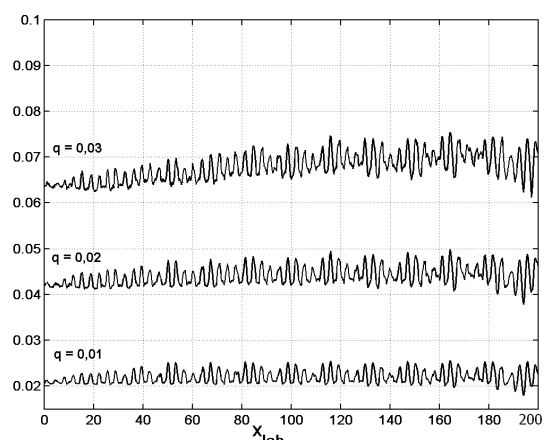

Gambar 1: Grafik nilai MTA, $\mathcal{M}(x)$, gelombang bikromatik dengan $\nu=0,155$ konstan dan untuk $q=0,01, q=0,02$, dan $q=0,03$.

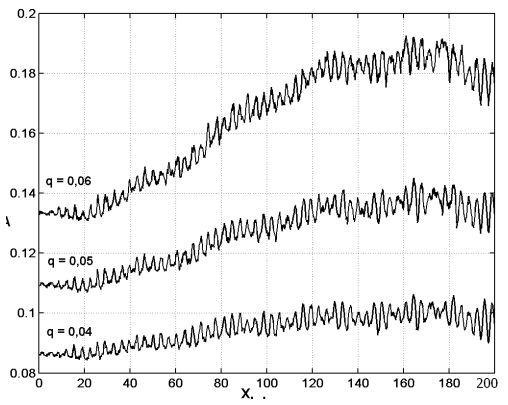

Gambar 2: Grafik nilai MTA, $\mathcal{M}(x)$, gelombang bikromatik dengan $\nu=0,155$ konstan dan untuk $q=0,04, q=0,05$, dan $q=0,06$.

deformasi spatial yang mudah teramati. Oleh karena itu grafik MTA ketiganya menunjukkan pola yang hampir sama.

Gejala deformasi spatial gelombang bikromatik mulai terlihat untuk $0,04 \leq$ $q \leq 0,06$. Gelombang-gelombang bikromatik dengan $0,04 \leq q \leq 0,06$ digolongkan sebagai gelombang moderat [8]. Grafik MTA ketiga gelombang moderat tersebut memperlihatkan FAA yang meningkat, seperti diperlihatkan dalam Gambar 2. Perubahan $F A A$ dan $x_{\max }$ yang signifikan terjadi untuk gelombang bikromatik dengan $0,07 \leq q \leq 0,09$ seperti diperlihatkan dalam Gambar 3. Menurut [8], gelombang yang dapat mencapai elevasi setinggi $5 \%$ kedalaman air digolongkan sebagai gelombang ekstrim. Dalam gambar tersebut terlihat bahwa tinggi MTA untuk $q=0,07$ mencapai $0,25 \mathrm{~m}$, yaitu $5 \%$ dari $h=5 \mathrm{~m}$. Dengan demikian gelombang bikromatik dengan $q \geq 0,07$ dapat digolongkan sebagai gelombang ekstrim. Amplitudo sebesar $q=0,08$ adalah amplitudo yang digunakan oleh Stansberg 


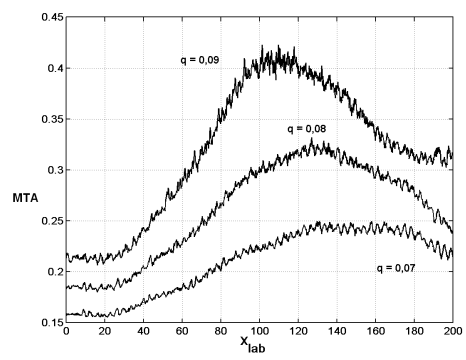

Gambar 3: Grafik nilai MTA, $\mathcal{M}(x)$, gelombang bikromatik dengan $\nu=0,155$ konstan dan untuk $q=0,07, q=0,08$, dan $q=0,09$.

dalam eksperimennya.

Gejala deformasi yang tidak signifikan pada kasus gelombang rendah dan gelombang moderat menimbulkan masalah dalam penentuan $x_{\text {max }}$. Dalam Gambar 1 dan 2 terlihat bahwa nilai MTA mencapai nilai maksimum yang hampir sama di beberapa posisi, sehingga tidak mudah menentukan posisi mana yang merupakan posisi maksimum yang sebenarnya. Untuk mengatasi masalah tersebut, dilakukan proses averaging (perata-rataan) dengan terlebih dahulu menentukan nilai maksimum dan minimum lokal $\mathcal{M}(x)$ di setiap posisi. Kemudian nilai ratarata diperoleh dengan mengambil rata-rata nilai maksimum dan minimum lokal di setiap posisi. Nilai rata-rata yang diperoleh di sini disebut sebagai hasil averaging I. Bila hasil averaging I belum dapat memberikan informasi yang meyakinkan, maka dilakukan proses averaging sekali lagi terhadap hasil averaging I atau diambil nilai rata-rata dua posisi maksimum yang berdekatan yang diperoleh dari hasil averaging $\mathrm{I}$.

Hasil perhitungan $x_{\max }$ yang telah melalui proses averaging dan hasil perhitungan $F A A$, dibandingkan dengan hasil yang diperoleh secara analitik dengan menggunakan AOT-KdV, disajikan dalam Tabel 1.

Pada kolom ke dua dan ke tiga Tabel tersebut diperlihatkan perubahan $x_{\max }$ bila $q$ berubah, berturut-turut dengan menggunakan data elevasi $\eta(x, t)$ yang diperoleh dari simulasi numerik HUBRIS dan yang diperoleh dari AOT-KdV. Terlihat bahwa nilai $x_{\max }$ mengecil bila $q$ bertambah. Untuk melihat pola kebergantungan $x_{\max }$ terhadap $q$, grafik $x_{\max }-q$ yang diperoleh secara numerik dibandingkan dengan grafik $x_{\max }-q$ yang diperoleh secara analitik dari AOT-KdV, seperti disajikan dalam Gambar 4 (a). Karena diperoleh pola yang hampir sama, dapat dikatakan bahwa $x_{\max }=\mathcal{O}\left(1 / q^{2}\right)$.

Dari kolom ke empat dan ke lima Tabel 1 dapat dilihat bahwa untuk $q \geq 0,03$, $F A A$ meningkat bila nilai $q$ membesar. Untuk melihat pola peningkatan $F A A$ 
Tabel 1: Pengaruh beda frekuensi dan amplitudo selubung signal di pembangkit gelombang terhadap Faktor Amplifikasi Amplitudo $(F A A)$ dan posisi maksimum MTA gelombang bikromatik.

\begin{tabular}{|c|c|c|c|c||c|r|r|r|r|}
\hline \multicolumn{9}{|c||}{$\nu=0,155$} & \multicolumn{5}{c|}{$q=0,07$} \\
\hline & \multicolumn{2}{|c|}{$x_{\max }$} & \multicolumn{2}{c|}{$F A A$} & & \multicolumn{2}{c|}{$x_{\max }$} & \multicolumn{2}{c|}{$F A A$} \\
\hline$q$ & HBR & AOT & HBR & AOT & $\nu$ & HBR & AOT & HBR & AOT \\
\hline \hline 0,010 & 162,6 & 156,5 & 1,238 & 1,025 & 0,6200 & 10,2 & 9,2 & 1,062 & 1,149 \\
\hline 0,020 & 158,5 & 154,1 & 1,191 & 1,050 & 0,4650 & 18,2 & 16,3 & 1,063 & 1,157 \\
\hline 0,030 & 149,9 & 150,3 & 1,190 & 1,083 & 0,3100 & 40,6 & 36,4 & 1,124 & 1,165 \\
\hline 0,040 & 141,6 & 145,3 & 1,240 & 1,121 & 0,2325 & 74,2 & 62,5 & 1,204 & 1,188 \\
\hline 0,050 & 139,3 & 139,3 & 1,333 & 1,161 & 0,1938 & 101,7 & 86,4 & 1,327 & 1,212 \\
\hline 0,055 & 137,2 & 136,0 & 1,379 & 1,187 & 0,1550 & 130,2 & 125,5 & 1,591 & 1,269 \\
\hline 0,060 & 135,0 & 132,6 & 1,452 & 1,214 & 0,1162 & 184,8 & 193,1 & 2,005 & 1,361 \\
\hline 0,065 & 133,4 & 129,1 & 1,527 & 1,242 & 0,0969 & 205,4 & 244,3 & 2,408 & 1,462 \\
\hline 0,070 & 130,2 & 125,5 & 1,591 & 1,269 & 0,0775 & 223,6 & 312,2 & 2,863 & 1,646 \\
\hline 0,075 & 127,6 & 121,9 & 1,694 & 1,293 & & & & & \\
\hline 0,080 & 126,0 & 118,2 & 1,806 & 1,315 & & & & & \\
\hline 0,085 & 123,0 & 114,6 & 1,879 & 1,344 & & & & & \\
\hline 0,090 & 111,0 & 110,9 & 1,975 & 1,379 & & & & & \\
\hline
\end{tabular}

terhadap $q$, dalam Gambar 4 (b) diperlihatkan kurva $F A A$ terhadap $q$ yang diperoleh secara numerik dengan menggunakan program paket HUBRIS dan yang diperoleh secara analitik dengan menggunakan AOT-KdV. FAA yang diperoleh melalui AOT-KdV lebih rendah daripada $F A A$ yang diperoleh secara numerik, sebab solusi yang diperoleh dari AOT-KdV menghasilkan interaksi tak linier antar mode yang terbatas hanya sampai orde ke tiga, sedangkan solusi yang diperoleh dari program paket HUBRIS menghasilkan interaksi tak linier antar mode hingga orde tinggi. Dalam [8, 15, 4, 9] diungkapkan bahwa sifat ketaklinieran, yang menyebabkan meningkatnya elevasi, meningkat bersama meningkatnya $q$. Oleh karena itu dapat dipahami bahwa semakin tinggi $q$ maka semakin cepat gelombang meninggi, sehingga posisi maksimum semakin dekat dan faktor amplifikasi juga semakin besar.

\subsection{Pengaruh Frekuensi}

Untuk melihat pengaruh frekuensi selubung gelombang bikromatik, $\nu$, terhadap $x_{\text {max }}$ dan $F A A$, amplitudo $q$ diambil konstan sedangkan $\nu$ diambil bervariasi dari 0,0775 sampai dengan 0,62. Dari Tabel 1 dapat diperiksa bahwa $x_{\max }$ berkurang sekitar 4 kali lipat bila nilai $\nu$ bertambah menjadi dua kali lipat, kecuali untuk 


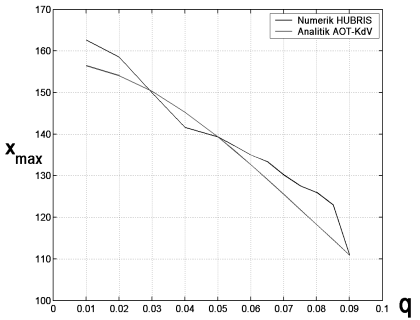

(a)

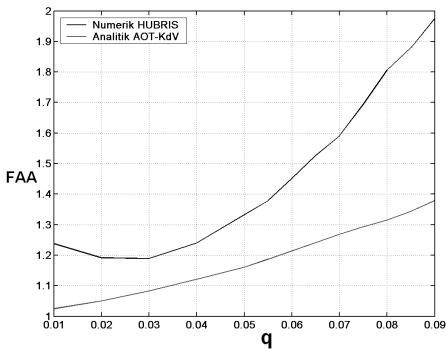

(b)

Gambar 4: (a) Grafik nilai $x_{\max }$ MTA terhadap $q$ dan (b) grafik $F A A$ terhadap $q$ yang diperoleh dari program paket HUBRIS (hitam) dibandingkan dengan hasil yang diperoleh dari AOT - KdV (merah), untuk gelombang bikromatik dengan nilai $\nu=0,155$ dan $\bar{\omega}=3,145$ konstan.

$\nu \leq 0,155$. Dengan demikian, untuk kasus ini, dapat dikatakan bahwa posisi maksimum MTA mendekati $\mathcal{O}\left(1 / \nu^{2}\right)$. Hasil ini sesuai dengan posisi maksimum yang diperoleh secara analitik dengan menggunakan AOT - KdV [3], yang diberikan pada persamaan (10). Perbandingan hasil perhitungan $x_{\max }$ secara numerik dan analitik tersebut disajikan secara grafis dalam Gambar 5 (a). Dalam Tabel 1 dan Gambar 5 (b) diperlihatkan bahwa nilai FAA berkurang bila $\nu$ bertambah. Dengan demikian untuk memperoleh faktor amplifikasi yang tinggi sebaiknya diambil nilai $\nu$ yang kecil. Namun, nilai $\nu$ kecil yang menghasilkan amplifikasi tinggi juga mengakibatkan peningkatan $x_{\max }$, sehingga bila diambil $\nu$ yang terlalu kecil gelombang akan mencapai maksimum di posisi yang jaraknya dari pembangkit gelombang dapat melampaui panjang kolam pengujian. Nilai $\nu=0,155$ memberikan nilai $F A A$ yang cukup tinggi dan posisi maksimum yang tidak terlalu jauh.

\section{Kesimpulan}

Telah dilakukan penyelidikan mengenai pengaruh amplitudo dan frekuensi selubung gugus gelombang bikromatik terhadap faktor amplifikasi dan posisi maksimum. Dari pengamatan nilai MTA dapat disimpulkan hal-hal berikut.

Pengaruh amplitudo dan frekuensi selubung terhadap posisi maksimum yang diperoleh melalui penyelidikan yang dilakukan secara numerik mendukung hasil yang diperoleh secara analitik dengan menggunakan aproksimasi orde ke tiga persamaan KdV. Posisi maksimum makin dekat ke posisi pembangkit gelombang bila amplitudo maupun frekuensi selubung membesar. Dapat disimpulkan, bahwa 


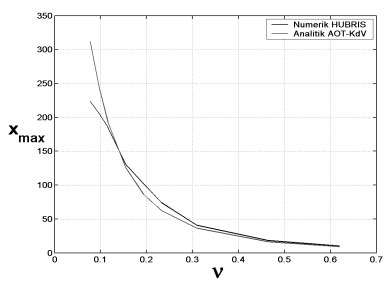

(a)

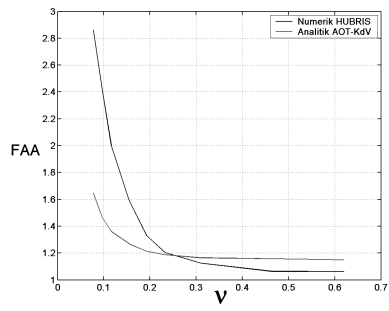

(b)

Gambar 5: (a) Grafik nilai $x_{\max }$ MTA terhadap $\nu$ dan (b) grafik $F A A$ terhadap $\nu$ yang diperoleh dari program paket HUBRIS (hitam), dibandingkan dengan hasil yang diperoleh dari AOT - KdV (merah), untuk gelombang bikromatik dengan $q=0,07$ konstan.

posisi maksimum MTA gelombang bikromatik berbanding terbalik dengan kuadrat amplitudo selubung signal di pembangkit gelombang. Di samping itu, posisi maksimum MTA gelombang bikromatik juga berbanding terbalik dengan kuadrat frekuensi selubung signal di pembangkit gelombang, asalkan nilai frekuensi selubung tidak terlalu kecil.

Nilai Faktor Amplifikasi Amplitudo (FAA) evolusi gelombang bikromatik dipengaruhi oleh besar amplitudo dan frekuensi selubung gugus signal bikromatik di pembangkit gelombang. Nilai FAA meningkat bila nilai amplitudo membesar. Sebaliknya, nilai FAA meningkat bila nilai frekuensi selubung mengecil. Hasil tersebut memberikan kecenderungan yang sama dengan hasil yang diperoleh secara analitik yang menggunakan aproksimasi orde ke tiga persamaan KdV dalam [3].

\section{Ucapan terima kasih}

Penulis mengucapkan terima kasih kepada Dr. Jaap-harm Westhuis atas diijinkannya penulis menggunakan program paket HUBRIS dalam penelitian ini. 


\section{Pustaka}

[1] Akhmediev dan A. Ankiewicz (1997), Solitons, nonlinear pulses and beams, Chapman \& Hall.

[2] Andonowati, dan van Groesen, E. (2003), Optical pulse deformation in second order non-linear media, Journal of Nonlinear Optical Physics \& Materials, 12, $221-234$

[3] Andonowati, Marwan, dan Kusumawinahyu, W. M. (2005), Phase effect on the Maximal Temporal Amplitude of down-stream running nonlinear water waves, dikirim ke ANZIAM Journal.

[4] Cahyono, E. (2002), Analitical wave codes for predicting surface waves in a laboratory basin, $\mathrm{PhD}$ Thesis, University of Twente, the Netherlands.

[5] Debnath, L. (1994), Nonlinear Water Waves, Academic Press, San Diego.

[6] Dingemans, M. W. (1997), Water wave propagation over uneven bottoms, Part 1: Linear Wave Propagation, volume 13 of Advanced series on ocean engineering, World Scientific, Singapore.

[7] van Groesen, E. (1998), Wave groups in uni-directional surface wave models, J. Eng. Math., 34, 215- 226.

[8] van Groesen, E., Andonowati, dan Soewono, E. (1999), Non-linear effects in bi-chromatic surface waves, Proc. Estonian Acad. Sci. Phys. Math., 48, 206 -229 .

[9] van Groesen, E. W. C. dan Westhuis, J. H. (2002), Modelling and simulation of surface water waves, Mathematics and computers in simulation, 59(4), 341 -360 .

[10] Korteweg, D. J. dan de Vries, G. (1895), On the change of form of long waves advancing in a rectangular canal, and on a new type of long stationary waves, Phil. Mag. and J. of Science, 39, $422-443$.

[11] Lo, E. dan Mei, C. C. (1985), A numerical study of water-wave modulation based on a higher order nonlinear Schrödinger equation, J. Fluid Mech., 150, $395-416$.

[12] Marwan dan Andonowati (2003), Wave deformation on the propagation of bi-chromatics signal and its effect to the maximum amplitude, JMS FMIPA ITB, vol. 8 no. $2,81-87$. 
[13] Stansberg, C. T. (1997), On the nonlinear behaviour of ocean wave groups, Proc. Waves '97, 2, 1227.

[14] Westhuis, J. H. (2001), The numerical simulation of nonlinear waves in a hydrodynamic model test basin, $\mathrm{PhD}$ thesis, University of Twente, the Netherlands.

[15] Westhuis, J. H., van Groesen, E., dan Huijsmans, R. H. M. (2001), Experiments and numerics of bichromatic wave groups, J. Waterway, Port, Coastal and Ocean Engineering, 127, 334 - 342. 